\title{
21. Diasporas izpratne nesenās migrācijas procesos
}

\author{
Aija Lulle
}

Ar diasporu mūsdienu Latvijā saprot ārpus valsts teritorijas dzīvojošus Latvijas iedzīvotājus, kuri jūtas piederīgi Latvijai. Taču diaspora ir politiski noteikts skaidrojums, kurš tiek lietots kopš 2010. gada, kad Latvijas Kultūras ministrija uzṇēmās koordinācijas darbu saikņu stiprināšanā ar diasporu. Kopš 2013. gada Ārlietu ministrijā (ĀM) izveidots īpašu uzdevuma vēstnieka postenis sadarbībai ar diasporu, kā arī darba grupa diasporas politikas jautājumos. Akadēmiski diasporas jēdziens ir strīdīgs: daļa pētnieku (piemēram, Robins Koens (Robin Cohen), 2008) uzsver, ka diasporas veidošanās ir vēsturiski noteikta un ka pastāv dažas klasiskas diasporas. Pārējos izceḷotājus klasiskā diasporas pieeja dēvē par emigrantiem. Savukārt citi (piemēram, Ho et al., 2015) diasporas jēdzienu attiecina arī uz nesen izcel̦ojušajiem, tai skatā tiem, kuri izcel̦oja pēc pašu vēlēšanās un kuriem nebija mērk,is veidot politiskas vai tirdzniecības saiknes ar izcelsmes valsti vai teritoriju. Terminologiski bēgḷ gaitās devušos sauca nevis par migrantiem, bet par trimdiniekiem, kas saskan ar pašidentifikāciju. Visi izbraukušie saskan,ā ar Latvijas valsts iestāžu politiku 21. gadsimtā tiek saukti par diasporas locekḷiem, lai uzsvērtu viņu Latvijas izcelsmi un piederību Latvijai.

Paturot prātā politisko aspektu un akadēmisko viedokḷu pretrunas, šajā nodaḷā jēdziens "diaspora" lietots, n,emot vērā politisko skaidrojumu un politiku iniciatīvas attiecībā uz iedzīvotājiem, kuri jūtas piederīgi Latvijai. Tas ietver visus, kuri agrāk tika dalīti kā "vecā trimda", "jaunie emigranti", "Rietumu diaspora" un "Austrumu diaspora" (Zelče, 2011). Savukārt, aprakstot izcel̦ošanas procesus, paralēli lietoti termini "izcel̦otāji”, "bijušie Latvijas iedzīvotāji”. Ja ir zināms, ka izcel̦ojušo uzskaitē norādīta Latvijas pilsonība, varam runāt par Latvijas pilsoņiem ārpus Latvijas. Taču daudzos gadījumos terminoloǵiski pareizāk būtu runāt par "Latvijas valstspiederīgajiem", ja nav zināma pilsonība, nav reǵistrēta tautība, bet ir zināms, ka personas izcel,ojušas no Latvijas. Turklāt migrācija notika arī pirms Latvijas valsts dibināšanas 1918. gadā, un par šiem izceḷotājiem varam norādīt, ka viṇi izceḷojuši no Latvijas teritorijas. 
Emigrācijas statistika visur pasaulē ir nepilnīga, tādēḷ nav iespējams norādīt pilnīgi precīzus datus, bet migrācijas apjoma noteikšanai lieto aplēses un pētnieku vērtējumu. Pēc aptuveniem ĀM Konsulārā departamenta datiem, ārpus Latvijas pastāvīgi dzīvo vairāk nekā 370 tūkst. Latvijas diasporas pārstāvju (ĀM, 2014). Skaits ietver tos, kuri Latvijas teritoriju atstājuši jau kopš 19. gadsimta beigām; bēgḷu gaitās devušos Pirmā pasaules kara laikā, pēc Otrā pasaules kara; izbraukušos PSRS laikā un pēc neatkarības atjaunošanas.

\section{Diasporas vēsturiskās, ġeogrāfiskās un demogrāfiskās iezīmes}

Izcel̦ošana no Latvijas teritorijas dažādos avotos datēta jau kopš viduslaikiem (Stradiņš, 2013), bet masveidā - ar 19. gadsimta beigām. Tālāk emigrācija turpinājās 20. gadsimta sākumā, sekojot lielākajiem viḷniem - deportācijām un bēgḷ gaitām Otrā pasaules kara laikā un pēc tā, un 20. gadsimta beigās pēc Latvijas neatkarības atjaunošanas, kad bija iespēja emigrēt no Latvijas un kad bijušais PSRS karaspēks, militārās personas un viṇu ǵimenes locekḷi izbrauca no Latvijas. Lielākās kopienas vēsturiski veidojās Amerikas Savienotajās Valstīs (ASV), Dienvidamerikā (īpaši Brazīlijā), Krievijā un Vācijā. Turpmāk aplēses norādītas pēc Veignera pētījumiem (Veigners, 2015), ja nav minēti vēl citi avoti.

ASV 19. gadsimta beigās un 20. gadsimta sākumā bija 16 veclatviešu kolonijas (Veigners, 2015, 64). Otrā pasaules kara laikā ieceḷoja 3-4 tūkst. latviešu. 1948. gadā pieḷāva baltiešu bēg̣̣u iebraukšanu, apejot ierasto ASV kvotu kārtību. Oficiālā statistika liecina, ka ar Starptautiskās bēgḷu organizācijas (International Refugee Organization, IRO) palīdzību līdz 1952. gadam ASV ieceloja apmēram 38 tūkst. latviešu.

Dienvidamerikas valstī, Brazīlijā, latvieši sāka ieceḷot 19. gadsimta beigās (600-800 latviešu). 1906. gadā 400-600 latviešu nodibināja Novaodesas koloniju. 1922.-1923. gadā Brazīlijā ieceḷoja 2,3 tūkst. latviešu un izveidoja "Vārpas" koloniju. Draudžu statistika liecina, ka šajos gados ieceḷojuši 3 tūkst. baptistu, savukārt IRO statistika - ka 1947.-1951. gadā izvietoti 800 latviešu bēg̣̣u.

Argentīnā 1930. gadā reǵistrēti 400-500 iebraukušie no Latvijas, un, pēc IRO datiem, 1947.-1951. gadā Argentīnā bija 650 cilvēku no Latvijas.

Čìlē 1947.-1951. gadā izvietoti 134 Latvijas pilsoṇi. Venecuēlā šajos gados izvietoti 745 Latvijas izcelsmes bēgli.

Izceḷošana uz Krieviju masveidā sākās 19. gadsimta otrajā pusē. 20. gs. 30. gados Krievijā bija vairāk nekā 300 latviešu koloniju. Otrā lielākā emigrācijas plūsma bija deportācijas 1941. un 1949. gadā. Trešā plūsma bija brīvprātīgi izbraukušie Otrā pasaules kara laikā un Padomju Savienības laikā. Pēc 1989. gada tautas skaitīšanas datiem, Krievijas teritorijā dzīvoja 30 tūkst. latviešu. Aplēsts, ka 2014. gadā Krievijā bija 15 tūkst. latviešu (Vlasova, 2014, 34-36).

Vācijā latvieši sāka ieceḷot vai nonāca karu dēḷ jau vismaz 17. gadsimtā. Migrācija, arī repatriācija, uz Latviju turpinājās 20. gs. 20. gados. 
30. gados Vācijā bija ap 2 tūkst. Latvijas pilsoṇu, bet latviešu - ap 300. Sākot ar 1939. gadu, Latviju atstāja 63 tūkst. pilsoṇu, no tiem ap 5-7,5 tūkst. latviešu. 1940.-1941. gadā turpinājās vācbaltu repatriācija; 1941.-1943. gadā atškìrīgās aplēsēs ap 35 tūkst. (svārstība no 16 līdz 52 tūkst.) Latvijas pilsoṇu tika nosūtîti obligātajā darba dienestā uz Vāciju. 1944.-1945. gadā, pēc atšķirīgiem avotiem, Vācijā bija 171-202 tūkst. bēgḷu no Latvijas (Hinkle, 2014; Veigners, 2015). "Mazās Latvijas" periodā (1945-1952) 100-135 tūkst. bēg̣̣lu no Latvijas dzīvoja nometnēs Rietumvācijā. 1945. gadā Vācijā darbību atjaunoja Latvijas Sarkanais Krusts. Latviešu centrālo kartotēku 1945. gadā sāka veidot arī Latviešu centrālā padome. Tajā ir personu uzskaites kartītes, kopā 142 tūkst. ierakstu.

1952. gadā Rietumvācijā vēl uzturējušies 14 tūkst. latviešu, 1960. gadā 13,1 tūkst., 1970. gadā 10-11 tūkst., 80. gados 9-10 tūkst. latviešu.

Nelielas kopienas jau 19. gadsimta beigās veidojās arī citviet pasaulē. Neraugoties uz vēsturiski niecīgu ieceḷotāju skaitu no Latvijas, Austrālija, Kanāda, Lielbritānija un Zviedrija papildus jau iepriekš minētajām mītnes zemēm izveidojās par nozīmīgām valstīm latviešu trimdiniekiem.

Pirmie ieceḷotāji no Latvijas Austrālijā un Jaunzēlandē reǵistrēti 19. gadsimta beigās. 1933. gadā uzskaitīti 500 no Latvijas ieceḷojušie pēdējo 60 gadu laikā, nenorādot tautību. Saskaņā ar Starptautiskās bēgḷu organizācijas un Austrālijas valdības līgumu 1947. gadā Austrālijā ieradās 19601 latvietis no pārvietoto personu nometnēm Vācijā (Didrihsone-Tomaševska, 2014, 240). Pirmās Kultūras dienas ar dziesmu svētkiem Austrālijā notika 1951. gadā.

1949.-1950. gadā ar IRO palīdzību Jaunzēlandē ieceloja ap 550 latviešu. 1952. gadā latviešu kopskaits Jaunzēlandē bija 22 tūkst., 1961. gadā 25,5 tūkst., 80. gados - 35 tūkst. (Veigners, 2015, 72). 60. gados Jaunzēlandē bija 700800 latviešu, bet 1993. gadā reǵistrētas 109 personas, 1997. gadā - 500 .

Lielbritānijā pirmie latvieši ieradās kā jūras braucēji 18.-19. gadsimtā (Kalniņš, 1995, 269). Pirms Pirmā pasaules kara tur dzīvoja 400-500 latviešu. 1946. gadā Lielbritānijas valdības Ārzemju strādnieku komiteja pieṇēma lēmumu aicināt darbiem slimnīcās baltiešu sievietes vecumā no 20 lîdz 40 gadiem ar sākotnēju uzturēšanās aț̣auju līdz 12 mēnešiem. Pirmās baltietes ieradās 1946. gada 19. oktobrī. Balt Cygnet (Baltijas gulbīšu) akcijas laikā 1946.-1948. gadā Lielbritānijā iebrauca 2,5 tūkst. latviešu, bet Westward Ho! (“Uz Rietumiem!") akcijas laikā 1947.-1950. gadā - 12 tūkst. latviešu. 1950. gadā vinu kopskaits sasniedza 18 tūkst., ieskaitot pirms kara dzīvojušos un radus. 1951. gadā šis skaits vērtēts ap 15 tūkst., 1961. gadā - 11 tūkst., bet 70.-80. gados -9 tūkst. latviešu (Andrups, 1995, 168-178). 1955. gada 23. oktobrī Londonā nodibināja Pasaules brīvo latviešu apvienību (PBLA) (ar toreizējo nosaukumu Brīvās pasaules latviešu apvienība, BPLA).

1944.-1945. gadā Kurzemes krastu ar laivām atstāja 8-8,5 tūkst. cilvēku, bet Zviedriju sasniedza 6-6,5 tūkst. 1945. gadā Zviedrijā oficiāli skaitījās 
3418 bēg̣̣lu no Latvijas, bet nebija uzskaitīti bērni un pusaudži. 50. gados bija 4,5 tūkst. personu no Latvijas, 60. gados sabiedriskā kārtā savāktas 1,5 tūkst. latviešu ğimeñu adreses. 1995. gadā Zviedrijā reợistrēti 1217 Latvijas pilsoṇi.

Latvijas iedzīvotāji mazākā skaitā apmetās arī citās valstīs. Beḷ̆gijā 1947.1951. gadā ar IRO palīdzību izvietoja 900 personu, kas bija izcel,ojušas no Latvijas, bet 1952. gadā to skaits samazinājās līdz 300 personām.

Dānijā 1944.-1945. gadā nonāca ap 2 tūkst. bēĝ̣u no Latvijas, bet 1948.1952. gadā 1,5 tūkst. no tiem aizbrauca uz citām valstīm. 50. gados Dānijā bija ap 400 latviešu. 1995. gadā Dānijā reǵistrēts 21 Latvijas pilsonis.

Francijā 30. gados bija 150 latviešu, bet ap 1,5-2 tūkst. citas tautības Latvijas pilsoṇu. 1947.-1951. gadā ar IRO starpniecību izvietoti 900 Latvijas pilsoṇu un vēl 50 Marokā. 50. gados Francijā bija ap 700-800, 80. gados 600 personu no Latvijas.

Kanādā no 1946. līdz 1955. gadam ieceḷoja ap 13 tūkst. latviešu, tai skaitā 8 tūkst. ar IRO starpniecību. Lìdz 1963. gadam ieceḷoja vēl ap 2,4 tūkst. latviešu (Veigners, 2015, 70). Jau 1949. gadā ASV, Kanādā un Austrālijā izveidoja latviešu skautu un gaidu vienības. Kopš 1952. gada dibināja plaša kultūras un izglītības spektra nometnes. ASV galvenās nometnes bija Katskiḷi, Garezers, Piesaule, Mežotne; Kanādā: Saulaine, Sidrabene, Tērvete; Austrālijā: Tērvete (Šķiñķe, Šķiņ̧̧is 2014). Pirmie Vispārējie latviešu dziesmu svētki ASV un Kanādā notika 1953. gadā.

Ķīnā daži simti no Latvijas iecelıjuši jau 1900. gadā, un 1918.-1919. gadā Ķīnā bija 2,5 tūkst. bēg̣̣u.

Nīderlandē 30. gados dzīvoja ap 120 Latvijas pilsoņu.

Uz Poliju Latvijas iedzīvotāji devās studēt jau 19. gs.; 30. gados tur dzīvoja ap tūkstoš Latvijas pilsoṇu. Šveicē 19. gadsimtā latvieši studēja; pēc 1905. gada revolūcijas devās uz turieni kā bēgḷi. 30. gados Šveicē dzīvoja ap 400 Latvijas pilsoṇu. Ar IRO starpniecību 1947.-1951. gadā tajā ieceḷoja ap 70 latviešu.

\section{Galvenās izmaiṇas un izaicinājumi diasporā kopš 1990. gada}

Saskaņā ar tautas skaitîšanas datiem 2011. gada 1. martā Latvijā bija 2070371 iedzīvotājs (salīdzinājumam: 2000. gadā - 2,38 milj.). Iedzīvotāju skaita samazinājums skaidrojams gan ar demogrāfiskiem, gan politiskiem, gan ekonomiskiem iemesliem. Tautas skaitǐšanas dati liecina, ka laika posmā no 2001. līdz 2011. gadam iedzīvotāju skaita samazinājums emigrācijas dēḷ ir ap 213 tūkst.

Pēc ĀM (2013) aptuveniem datiem un aplēsēm, lielākās latviešu kopienas, kas veidojušās migrācijas dẹl, 21. gadsimta pirmajā desmitgadē ir Lielbritānijā (ap 100 tūkst.), ASV (pēdējā tautas skaitǐšanā ASV 96 tūkst. iedzīvotāju uzrādīja latvisku izcelsmi; ASV šobrīd dzīvo ap 15 tūkst. Latvijas Republikas pilsoṇu), Kanādā (ap 26 tūkst.), İrijā (25-30 tūkst.), Zviedrijā (ap 30 tūkst.), 
Austrālijā (ap 25 tūkst.), Krievijā (ap 20 tūkst.), Brazīlijā (līdz 20 tūkst.), Vācijā (ap 30 tūkst.), Norvēǵijā (ap 11 tūkst.) un Spānijā (ap 7 tūkst.). ĀM Konsulārā departamenta dati apliecina, ka izceḷotāju skaits no Latvijas uz daudzām ES dalïbvalstìm turpina pieaugt.

Pēc Latvijas neatkarības atjaunošanas pakāpeniski palielinājās iespējas doties uz ārzemēm, īpaši Eiropas valstīm. CSP dati uzrāda, ka no 2000. līdz 2017. gadam prom no Latvijas devušies 409,6 tūkst. iedzīvotāju, kas kopā veido 17,2\% no Latvijas kopējā iedzīvotāju skaita 2000. gada sākumā. Emigrācijas plūsmu lielākie apjomi raksturīgi finanšu un ekonomiskās krīzes periodā (2008-2012), bet mūsdienās tie ir mazinājušies un, uzlabojoties Latvijas ekonomiskajai situācijai un darbavietu pieejamībai, lēnām sasniedz pirmskrīzes emigrācijas apjomus.

Eiropas Latviešu apvienība ir aplēsusi, ka Eiropā dzīvo ap 200 tūkst. iedzīvotāju, kas izbraukuši no Latvijas.

Lìdz šim lielākajā emigrantu interneta aptaujā 2014. gadā atbildes sniegtas no 118 pasaules valstīm (Mierina, 2015).

Turpmāk ir norādīts atsevišķajās valstīs esošais Latvijas izcelsmes personu skaits 21. gadsimta sākumā pēc Veignera datiem (Veigners, 2015), ja nav norādìts citādi.

Pēc Amerikas kopienu aptaujas (American Community Survey, 2006-2010) datiem, ASV 91096 iedzīvotāji uzrāda latvisku izcelsmi, no tiem 41851 persona uzrādīja savu senču piederību tikai latviešu etniskajai grupai (Garoza, 2014, 186). Krietni mazāks ir to ASV iedzīvotāju skaits, kam ir Latvijas pilsoṇa statuss. Pēc Latvijas PMLP datiem, 2017. gadā ASV reǵistrēti 14,5 tūkst. Latvijas pilsoṇu.

Pēc tautas skaitīšanas datiem, 2006. gadā Austrālijā 20058 personas sevi dēvēja par latviešiem vai par Latvijas izcelsmes personām. 2017. gadā PMLP ziņoja par 5,4 tūkst. Latvijas pilsoṇu, kas dzīvoja Austrālijā, kamēr Jaunzēlandē to bija 229.

Dienvidamerikā, Brazīlijā, 2006. gadā bija 10 tūkst. iedzīvotāju ar Latvijas izcelsmi, kā arī 230 Latvijas pilsoṇu. 2017. gadā, pēc PMLP datiem, tiek ziņots par 327 Latvijas valsts piederīgajiem.

Argentīnā 2006. gadā uzskaitīti 152 Latvijas pilsoṇi, bet 2017. gadā - 177.

Austrijā 2006. gadā bija 383 Latvijas pilsoni, bet 2017. gadā šis skaits ir gandrīz divreiz pieaudzis - līdz 676.

Beḷgijā 2006. gadā uzturējās 335 Latvijas pilsoṇi, bet 2017. gadā jau 1017.

Dānijā 2006. gadā dzīvoja ap 500 latviešu izcelsmes personu. Tas skaidrojams ar to, ka 1921. gadā zīmīgs skaits Latvijas pilsoṇu Dānijā iecelıjoja, lai strādātu vai studētu. Tādējādi 2017. gadā Latvijas pilsoṇu skaits Dānijā bija sasniedzis 1520 .

Tautas skaitīšanas rādītājos reǵistrētie latvieši Kanādā: 2001. gadā 22,6 tūkst. un 2011. gadā 27,4 tūkst. Taču kā Latvijas pilsoṇi 2002. gadā 
bija reǵistrētas 4102 personas. 2017. gadā, pēc PMLP datiem, Kanādā dzīvoja 4920 Latvijas pilsoniu.

İrijā 2003. gadā darba atḷaujas bija 4 tūkst. personu, kas iebraukušas no Latvijas; aplēses liecināja, ka pavisam to ir 10 tūkst. Pēc İrijas nodokḷu administrācijas datiem, 2005. gadā İrijā bija 23 tūkst. Latvijas pilsoṇu, pēc sociālās apdrošināšanas numuriem (PPS) - 24 tūkst. Pēc İrijas Nacionālā statistikas biroja (Central Statistics Office) 2006. gada tautas skaitīšanas datiem, valstī dzīvoja 17,2 tūkst. Latvijas valsts piederīgo, bet 2011. gadā tautas skaitīšanā reǵistrēti jau 20,6 tūkst. Interesanti, ka 2016. gadā Latvijas valsts piederīgo skaits İrijā bija samazinājies līdz 19,9 tūkst. Savukārt PMLP 2017. gadā ziņoja, ka İrijā dzīvo 18,5 tūkst. Latvijas valsts piederīgo, no kuriem 18,8 tūkst. bija Latvijas pilsoni, bet 220 - nepilsoni.

Islandē 2017. gadā dzīvoja 283 Latvijas pilsoṇi.

Griekijā pēc 2004. gada bija 500 latviešu. 2014. gadā Saeimas vēlēšanās Atēnās nobalsoja 85 pilsoṇi. PMLP dati par 2017. gadu rāda, ka Griekiijā šajā gadā dzīvoja 305 Latvijas pilsoṇi. Aplēsts, ka Kiprā pēc 2004. gada bija 1-2 tūkst. iedzīvotāju, kas iebraukuši no Latvijas. 2017. gadā PMLP ziṇoja, ka Kiprā dzīvo 575 Latvijas pilsoṇi.

Francijā 2011. gadā dzīvoja ap 1,8 tūkst. latviešu, bet 2017. gadā 2315 Latvijas pilsoṇu.

Lielbritānijā 2002. gadā dzīvoja 2649 Latvijas pilsoṇi. Pēc Lielbritānijas nacionālās apdrošināšanas numuru (National Insurance Number application (NINo)) datiem, 2002.-2010. gadā bija 120 tūkst. no Latvijas iebraukušo reǵistrēto personu. Pēc strādājošo reǵistrācijas sistēmas (Worker Registration Scheme, WRS) datiem, 2004.-2011. gadā Lielbritānijā bija 80 tūkst. reǵistrēto personu no Latvijas. Iebraukušo Latvijas iedzīvotāju skaita maksimums Lielbritānijā bija 2010. gadā, kad gada laikā reǵistrētas 28280 personas (Apsīte-Beriṇa, 2013). Kā ziņo PMLP, 2017. gada sākumā Lielbritānijā dzīvoja 62,2 tūkst. Latvijas pilsoṇu.

Luksemburgā 2006. gadā dzīvo ap 500 cilvēku, kas iebraukuši no Latvijas, bet PMLP dati liecina, ka 2017. gadā tajā mìt 332 Latvijas pilsoṇi.

Norvēǵijā, pēc tās statistikas datiem, 2005. gadā dzīvoja 338 Latvijas pilsoṇi, bet 2017. gadā, pēc PMLP zin̄ām, jau 2644.

Nìderlandē 2006. gadā bija 2,5 tūkst. Latvijas pilsoṇu, bet 2011. gadā jau 4,2 tūkst. PMLP dati par 2017. gadu liecina, ka Latvijas pilsoṇu skaits Nīderlandē ir krietni mazāks - 1,7 tūkst.

Polijā, pēc statistikas aplēsēm, 2006. gadā dzīvoja aptuveni 100 Latvijas pilsoṇu, savukārt 2017. gadā PMLP ziņo par 238.

Portugālē 2013. gadā bija 400 Latvijas pilson,u, bet 2017. gadā, pēc PMLP ziṇām, vien 190.

Somijā Latvijas pilsoṇu skaits audzis: no apmēram 30 cilvēkiem 20. gs. 30. gados un 20 cilvēkiem 1990. gadā līdz vienam tūkstotim 2010. gadā. 2017. gadā PMLP ziņo par 1007 Latvijas pilsoṇiem šajā valstī. 
Spānijā 2006. gadā bija apmēram 1,5 tūkst. Latvijas pilsoṇu, 2008. gadā ap 3 tūkst., kas bija san̦ēmuši uzturēšanās atḷauju. 2017. gadā Spānijā dzīvoja 1,6 tūkst. Latvijas pilsonu.

Šveicē 2006. gadā bija uzskaitīti 611 Latvijas pilsoṇu, 2017. gadā šis skaits sasniedza 1,2 tūkst.

Vācijā 2002. gadā reǵistrēti 2784 Latvijas pilsoṇi, bet latviešu tautības cilvēku kopskaits bija ap 8,5 tūkst., ieskaitot gan ilgstoši tur dzīvojušos, gan nesen ieradušos. Pēc Vācijas statistikas datiem, 2006. gadā reǵistrēti ap 9,5 tūkst., bet 2010. gadā beigās - 15 tūkst. Latvijas izcelsmes personu, 2012. gadā Vācijā dzīvoja 21,790 tūkst. Latvijas pilson,u. PMLP dati par 2017. gadu rāda, ka Vācijā dzīvoja 14,4 tūkst. Latvijas pilsoņu.

Zviedrijā 2002. gadā reg̣istrēti 1405 Latvijas pilsoṇi. 2017. gadā šis skaits sasniedzis 3616.

Informāciju par citās Eiropas valstīs dzīvojošo Latvijas pilsoṇu skaitu sniedz arī Eurostat, un šis skaits atšķiras no PMLP datiem. Kā redzams 21.1. attēlā, 2012. gadā lielākais Latvijas pilsoṇu skaits dzīvoja Lielbritānijā (64,8 tūkst.), Īrijā (21,2 tūkst.) un Vācijā (19,8 tūkst.).

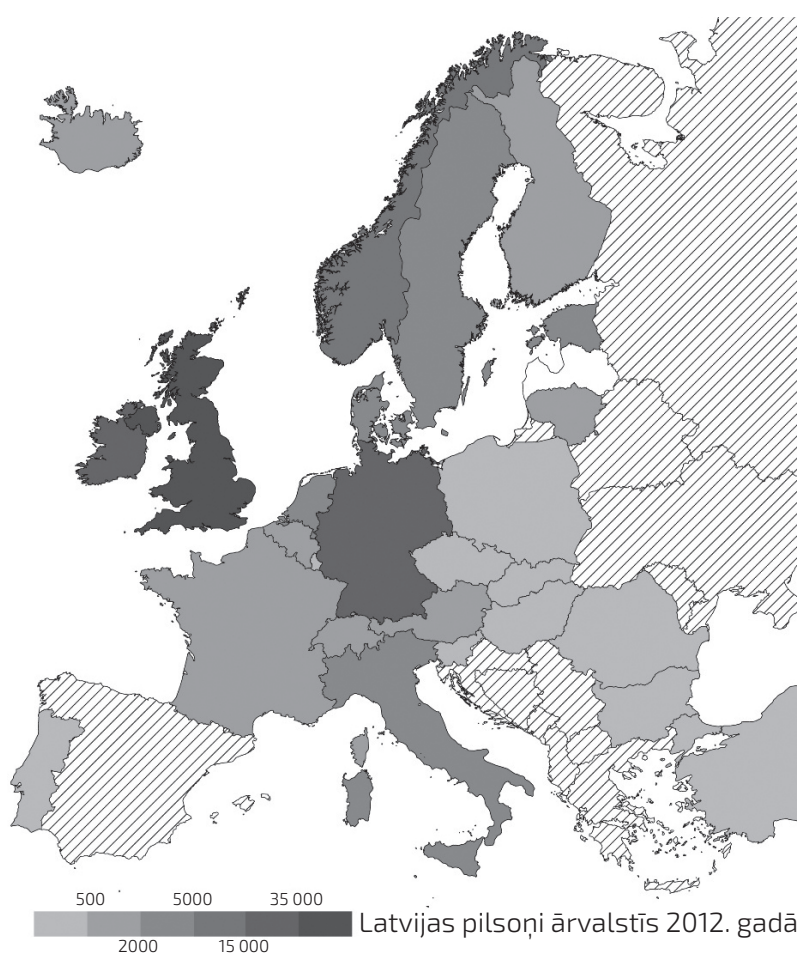

21.1. attēls. Eiropā dzīvojošo Latvijas pilsoṇu skaits 2012. gadā

Avots: veidojusi autore, izmantojot Eurostat datus [migr_pop1ctz]. 


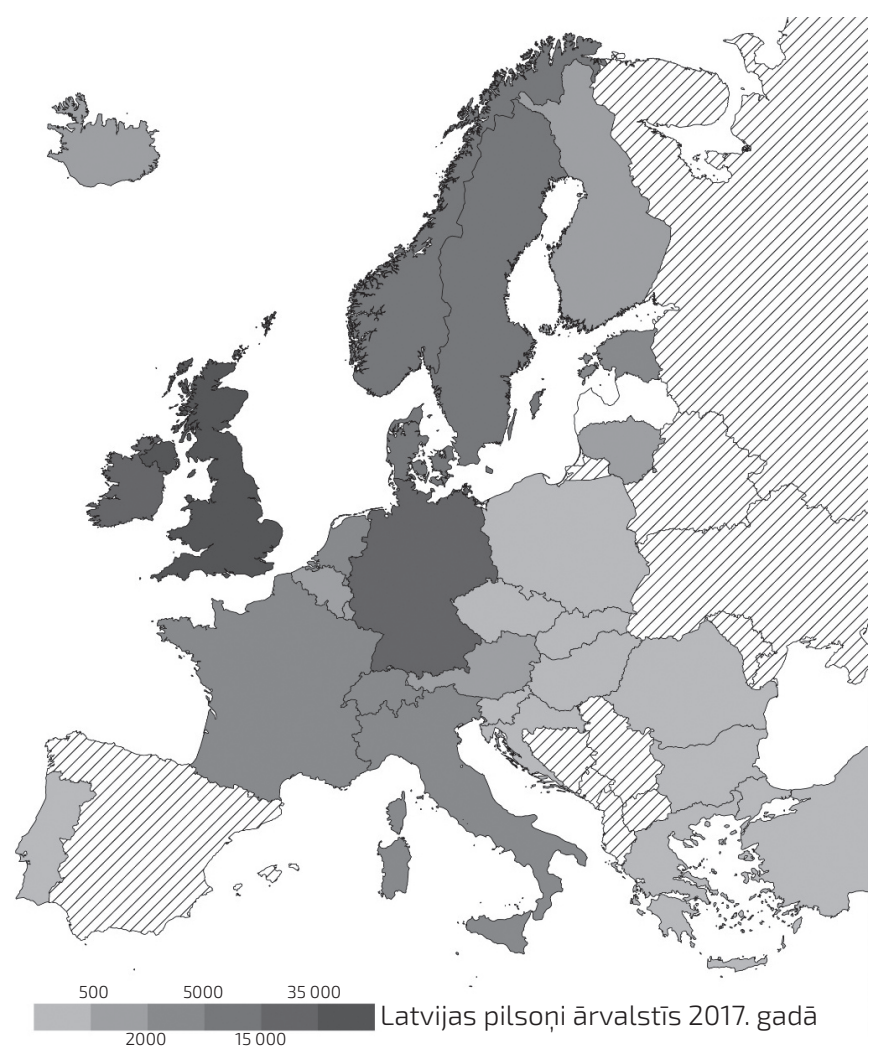

21.2. attēls. Eiropā dzīvojošo Latvijas pilsoṇu skaits 2017. gadā Avots: veidojusi autore, izmantojot Eurostat datus [migr_pop1ctz].

2017. gadā lielākais Latvijas pilsoṇu skaits joprojām dzīvoja Lielbritānijā (100,1 tūkst.), Vācijā (31,6 tūkst.) un Īrijā (20,6 tūkst.). Kopumā Eurostat sniedz informāciju par Latvijas pilsoṇu skaitu 29 Eiropas valstīs. 27 no tām kopš 2012. gada sākuma Latvijas valsts piederīgo skaits ir pieaudzis. Izṇēmumi ir İrija un Portugāle. Tādējādi, aizstājot İriju, par otro iecienītāko Latvijas pilsoņu migrācijas galapunktu piecu gadu laikā kḷuvusi Vācija.

\section{Sabiedrības atjaunošana un diaspora: saikṇu stiprināšana}

Emigrāciju, pirmkārt, ietekmē ekonomiskā situācija un visvairāk - atalgojuma atšķirības par labu valstīm, uz kurām cilvēki izbraukuši (Krišjāne u. c., 2007). Atgriešanās migrāciju var ietekmēt ekonomiskā situācija mītnes zemēs, piemēram, krīze, pieaugošs bezdarbs. Taču krīze, piemēram, Lielbritānijā, kas ir populārs galamērḳis, var veicināt ne vien atgriešanos dzimtenē, bet tālāku izbraukšanu uz citām valstīm. 
Latviešu tīklošanās aktivitātes ārzemēs, otrkārt, ietekmē politiskā dinamika un interese par notikumiem dzimtenē, dalība vēlēšanās, kandidēšana uz amatiem Latvijā, kopīgu interešu kopu uzturēšana un likumu izmaiṇu lobēšana, piemēram, nodokḷu, sociālajos, pilsonības un izglītības jautājumos. Politiski visnozīmīgākās pārmaiņas bija Latvijas iestāšanās ES un darba tirgus atvēršana ES valstīs, tas radīja apstākḷus brīvā darba tirgus kustībai. Saiknes uzturēšanu ar Latviju, dzīvojot ārzemēs, veicina dubultpilsonības iespēja.

Izbraukšanu uz laiku vai ilgstoši ietekmēt arī globalizācija - aizvien plašākas iespējas sazināties, kā arī pieejamie transporta tīkli. Latvijas Ekonomikas ministrija (EM, 2013) izstrādāja "Reemigrācijas atbalsta pasākumu plānu 2013.-2016. gadam”, kurā bija paredzēti daudzpusīgi pasākumi atpakaḷmigrācijas veicināšanai. Tā ietvaros divus gadus norisinājās diasporas jauniešu stipendiju programma, radot iespējas atrast darbu valsts iestādēs tiem, kuri izglītību ieguvuši ārvalstīs. Taču daudzi pasākumi netika īstenoti līdzekḷu trūkuma dēḷ, tai skaitā iecere par vienas pieturas aǵentūru, kurā visi, kuri vēlas atgriezties, vienkopus varētu uzzināt nepieciešamo informāciju par dzīvesvietas, darba, skolu, veselības un citiem jautājumiem.

\section{Dubultpilsonība - iespējas un izaicinājumi sabiedrības atjaunošanā}

Būtisks normatīvā ietvara pavērsiens sabiedrības atjaunošanā tautas daḷā ārpus Latvijas robežām ir iespēja iegūt dubultpilsonību arī tiem Latvijas iedzīvotājiem, kuri, piemēram, saviem bērniem, bija izvēlējušies tikai vienu citas valsts pilsonību.

Sākot ar 2013. gada 1. oktobri, stājušies spēkā grozījumi Latvijas Pilsonības likumā (1994), kas paredz iespēju ārzemēs dzīvojošajiem latviešiem pieteikties Latvijas pilsonībai vai dubultpilsonībai. Trimdas latvieši un viṇu pēcteči jau varēja iegūt dubultpilsonību līdz 1995. gadam, bet daudzi nepaspēja to izdarīt. Taču 2013. gada grozìjumos ir noteikti ierobežojumi valstīm, ar kurām ir piel̦aujama vai nav piel̦aujama dubultpilsonība. To atḷauts iegūt kopā ar citas ES dalībvalsts vai Eiropas Brīvās tirdzniecības asociācijas dalībvalsts pilsonību, citas Ziemel̦atlantijas līguma organizācijas (NATO) dalībvalsts pilsonību, Austrālijas Savienības, Brazilijas Federatīvās Republikas vai Jaunzēlandes pilsonību, tādas valsts pilsonību, ar kuru Latvija ir noslēgusi līgumu par dubultās pilsonības atzīšanu (lai gan grozījumu pieņemšanas laikā neviens līgums nebija noslēgts), iepriekš neminētas valsts pilsonību, ja saistībā ar svarīgām valsts interesēm būs saṇemta Ministru kabineta aț̣auja saglabāt dubultpilsonību, iepriekš neminētas valsts pilsonību, ja tā iegūta automātiski, apprecoties vai adopcijas dēḷ.

Jāuzsver, ka Latvijas pilsoņu bērniem dubultpilsonība ir iespējama ar jebkuru valsti. Tādējādi dubultpilsonības atḷaušana ir izteikti vērsta uz ataudzes 
un sabiedrības atjaunošanas mērķiem, kurā diaspora tiek uztverta kā neatņemama Latvijas tautas un pilsoṇu kopuma daḷa.

\section{Nobeigums: valsts un diasporas mijiedarbība sabiedrības atjaunošanā}

Latviešu skaita ārzemēs pilnīgākai aplēsei ieteicams pilnveidot emigrācijas un atpakaḷmigrācijas statistiku. Prognozēt emigrācijas plūsmas ilgtermiṇā apgrūtina daudzu faktoru kopums, tai skaitā politikas, ekonomikas, drošības un citi jautājumi atšķirīgās valstīs, kurās mīt no Latvijas izbraukušie. Līdzdalība Saeimas vēlēšanās ir relatīvi zema.

Latviešu skaitu un aktivitātes ārzemēs veicina gan pašiniciatīva, gan Latvijas valsts, sabiedrisko organizāciju, uzṇēmēju, radu un draugu kontakti. Atpakaḷmigrācijas un sadarbības ar diasporu veicināšanai jāṇem vērā demogrāfiskās tendences, t. sk. 21. gadsimta sākumā izbraukušo pakāpeniska novecošana.

Jāveicina kultūras uz izglītības saikṇu pilnveide, īpaši latviešu valodas apguvē un nostiprināšanā. Lìdzdalībai liela mēroga kultūras pasākumos Latvijā ir tendence pieaugt. Kopš 1990. gada dziesmu un deju svētkos Latvijā piedalās ārzemju latviešu kolektīvi. Pēc Latvijas Nacionālā kultūras centra datiem, 2013. gadā dziesmu un deju svētkos Latvijā piedalījās 48 ārvalstu latviešu kolektīvi, kopskaitā ar 1300 dalībniekiem. 2018. gadā XXVI Vispārējos latviešu dziesmu un XVI deju svētkos ir piedalījušies 5500 diasporas latviešu no 21 valsts.

Jāturpina dokumentēt un pētīt ārzemju latviešu dzīves gaitas. 1992. gadā uzsākta trimdas dokumentārā mantojuma veidošana. Tas uzkrāts kopš 1944. gada, kad sākās iedzīvotāju evakuācija un bēgḷu plūsmas uz Vāciju (Kalniņa, 2014, 259). 1948. gadā tika noslēgts līgums par Latviešu centrālās komitejas bēgḷu dzīves arhīva dokumentu nodošanu glabāšanā Stenfordas Universitātes Hūvera institūta arhīvā. Nodotie dokumenti ir mikrofilmēti un pieejami Latvijas Nacionālajā arhīvā (Kalniṇa, 2014, 261). Latvijas Nacionālajā arhīvā daudzi trimdinieki ir nodevuši personīgos arhīvus.

\section{Literatūra un avoti}

Andrups, J. (1995) Lielbritanijas latviešu vēsture. Grām.: Auziṇa-Smita, I. (red.) Latvieši Lielbritanijā. Pirmā grāmata, 1.-266. lpp.

Apsīte-Beriņa, E. (2013) Starptautiskā migrācija Eiropas Savienībā: migrācija no Latvijas uz Lielbritāniju. Doktora disertācija. Rīga: Latvijas Universitāte.

Cohen, R. (2008) Global Diasporas. An Introduction. New York: Routledge.

Didrihsone-Tomaševska, I. (2014) Latvijas diplomātiskie pārstāvji Austrālijā (1921-1991) Latvija ārpus Latvijas. Kultūra, vēsture, emigrācija un nacionālā identitāte. Konferences referātu krājums. Kḷaviṇa, D. (red.) Rīga: Latvijas Nacionālais arhīvs. 
Ekonomikas ministrija (EM) (2013) Reemigrācijas atbalsta pasākumu plāns 2013.-2016. gadam. Rīga: Latvijas Ekonomikas ministrija.

Garoza, I. (2014) Zem viena (skolas) jumta: Amerikas latviešu skolu loma 2. pasaules kara un atgūtās neatkarības laika emigrantu saliedēšanā. Latvija ārpus Latvijas. Kultūra, vēsture, emigrācija un nacionālā identitāte. Konferences referātu krājums. Kḷaviņa, D. (red.) Rīga: Latvijas Nacionālais arhīvs, 185.-192. lpp.

Hazans, M. (2015) Emigrācija no Latvijas 21. gadsimtā reǵionu un novadu griezumā. Latvijas emigrantu kopienas: cerïbu diaspora. Mieriņa, I. (zin. red.) Rīga: LU FSI, 11.-25. lpp.

Hazans, M. (2011) Latvijas emigrācijas mainīgā seja: 2000-2010 (The Changing Face of Latvia's Emigration: 2000-2010). In: Zepa, B., Klave E. (eds.) Latvia. Human Development Report 2010/20119. Riga: University of Latvia, pp. 70-91.

Hinkle, M. (2014) Amerikas latviešu apvienības mutvārdu vēstures projekts (ASV) "Latvieši pasaulē - muzejs un pētniecības centrs" (Latvija). Latvija ārpus Latvijas. Kultūra, vēsture, emigrācija un nacionālā identitāte. Konferences referātu krājums. Kḷaviṇa, D. (red.) Rīga: Latvijas Nacionālais arhīvs, 306.-318. lpp.

Ho, E. L. E., Hickey, M., Yeoh, B. S. A. (2015) Editorial: Special Issue Introduction: New Research Directions and Critical Perspectives on Diaspora Strategies, Geoforum, 59: 153-158.

Kalniņa, I. (2014) Latviešu trimdas dokumentārais mantojums Latvijas Nacionālajā arhīvā. Latvija ārpus Latvijas. Kultūra, vēsture, emigrācija un nacionālā identitāte. Konferences referātu krājums. Kḷaviṇa, D. (red.) Rīga: Latvijas Nacionālais arhīvs, 259.-266. lpp.

Kalniņš, Ā. (1995) Latviešu jūru braucēji ierodas Lielbritānijā. Grām.: Auziṇa-Smita, I. (red.) Latvieši Lielbritanijā. Pirmā grāmata, 269.-270. lpp.

Krišjāne, Z., Eglīte, P., Bauls, A., Lulle, A., Bērziņš, M., Brants, M., Cunska, Z., Gñedovska, I., Ivbulis, B., Krūzmētra, Z., Kūle, L., Markausa, I. M., Niklass, M., Pavlina, I., Titova, N., Vanaga, S., Vilciņš, A., Zariņa, I. B. (2007) Darbaspēka ǵeogrāfiskā mobilitāte. Rīga: LU; Labklājības ministrija.

Mieriṇa, I. (2015) Latvijas emigrantu kopienas: nacionāla identitāte, transnacionālās attiecības un diasporas politika. Galvenās atzinas [http://www.slideshare.net/lufsi/latvijas-emigrantu-kopienas-galvens-atzias (29.05.2017.)].

Stradiņš, J. (galv. red.) (2013) Latvieši un Latvija, 4. sēj. Rīga: Latvijas Zinātṇu akadēmija.

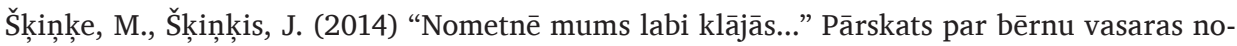
metnēm ASV, Kanādā, Austrālijā. Latvija ārpus Latvijas. Kultūra, vēsture, emigrācija un nacionālā identitāte. Konferences referātu krājums. Kḷaviṇa, D. (red.) Rīga: Latvijas Nacionālais arhīvs, 200.-207. lpp.

Veigners, I. (2015) Latvieši Rietumzemēs. Rīga: Ilgvara Veignera izdevniecība.

Vlasova, L. (2014) Latviskā kultūra Krievijā. Latvija ārpus Latvijas. Kultūra, vēsture, emigrācija un nacionālā identitāte. Konferences referātu krājums. Kḷaviṇa, D. (red.) Rīga: Latvijas Nacionālais arhīvs, 34.-37. lpp.

Zelče, V. (2011) Migrācijas lielākās plūsmas. 19. gs. sākums - 1991. gads. Grām.: Latvija. Pārskats par tautas attīstību: 2010/2011. Nacionālā identitāte, mobilitāte un rīcibspēja. Rìga: LU Sociālo un politisko pētījumu institūts, 49.-63. lpp.

\section{Politikas dokumenti}

ĀM (2014) Rīcības plāns "Par sadarbību ar Latvijas diasporu 2015.-2017. gadam" [http:// www.mfa.gov.lv/data/file/AMPlans_150714_Diaspora.662.pdf (12.04.2017.)].

CSP (2012) Tautas skaitī̌anas dati [https://www.csb.gov.lv/lv/statistika/statistikas-temas/ iedzivotaji/tautas-skaitisana/2011 [(12.04.2017.)]. 
EM (2013) Reemigrācijas atbalsta pasākumu plāns 2013.-2016. gadam. Rīga: LR Ekonomikas ministrija [http://polsis.mk.gov.lv/documents/4428 (12.04.2017.)].

Latviešu pēdas pasaulē [http://pedas.lapamuzejs.lv/?page_id=545 (12.04.2017.)].

Pasaules Brīvo latviešu apvienība. Elektroniskā mājaslapa [http://www.pbla.lv/].

Pilsonības likums (1994) [http://likumi.lv/doc.php?id=57512 (29.05.2017.)].

PMLP (2018) Latvijas valstspiederīgo personu skaits ārvalstīs uz 1.01.2017. [http://www. pmlp.gov.lv/lv/sakums/statistika/iedzivotaju-registrs/ (12.07.2018.]. 